\title{
ЗАБЕЗПЕЧЕНІСТЬ УКРАЇНСЬКОГО РИНКУ БУДІВЕЛЬНОЇ ТЕХНІКИ ВАНТАЖОПІДЙОМНИМ ОБЛАДНАННЯМ ТА ЙОГО СЕРВІСНИМ ОБСЛУГОВУВАННЯМ
}

\section{PROVISION OF THE UKRAINIAN MARKET OF CONSTRUCTION EQUIPMENT WITH LIFTING EQUIPMENT AND ITS SERVICE}

\section{Пахолюк О.А., к.т.н., доц., Чапюк О.С., к.т.н., доц., (Луцький національний технічний університет, м. Луцьк)}

Pakholiuk O., Ph.D. in Engineering, Associate Professor, Chapiuk O., Ph.D. in Engineering, Associate Professor, (Lutsk National Technical University, Lutsk)

Досліджено питання актуального рівня будівельного виробництва в Україні, умови успішного ведення будівельних робіт на різноманітних майданчиках та об'єктах та значення при иьому вантажопідйомної техніки. Проведено огляд основних постачальників та сервісних цеентрів будівельних кранів провідних світових виробників, присутніх на будівельному ринку України. (Стаття оглядова)

In January-March 2020, Ukrainian enterprises performed construction works in the amount of UAH 26,082.8 million. The index of construction products is $94.5 \%$ compared to the corresponding period of 2019. New construction accounted for $46.7 \%$ of the total output, capital and current repairs - $25.8 \%$, reconstruction and technical reequipment $-27.5 \%$.

This year's decline in the construction industry is, of course, due to the COVID-19 pandemic. However, even with a certain decline in volume, the number of works being carried out is significant. It is quite natural that these works cannot be performed without lifting equipment.

Construction machines, especially cranes, work in difficult conditions on a variety of sites, foundations and objects. High quality and accuracy of work along with the reliability, durability and maintainability of equipment will be crucial in choosing a machine to perform a particular job. Therefore, extremely important points are the ability to timely deliver the crane, which must meet the needs of the customer, timely maintenance and overhaul, maintenance, quickly provide the necessary spare parts and materials. Therefore, a developed network of service companies in Ukraine can be an important factor in choosing both lifting and other equipment.

A review of the offers of cranes in the network showed about 5 thousand offers of rent and sale of cranes. From this sample we can draw the following conclusions: with a total of 150 manufacturers, more than 10-20 proposals are found from 33 manufacturers, and more than 50 - only from 13 manufacturers of construction cranes. We will analyze the offers and service from these manufacturers on the Ukrainian market of lifting equipment.

The following conclusions can be drawn from the study: 
The construction market requires a significant number of lifting machines for various purposes and characteristics. In Ukraine, there are a number of organizations with significant experience in the sale, repair and maintenance of cranes, which act as official dealers and certified service centers. On the territory of Ukraine construction equipment of all leading world manufacturers is used. The offer of crane equipment manufacturers completely covers the need of the construction market for high-quality lifting equipment to perform from the simplest to the most difficult tasks. (Review article)

Ключові слова: будівельна індустрія, будівельні машини, крани, вантажопідйомна техніка, офіиійний дилер.

Keywords: construction industry, construction machines, cranes, lifting equipment, official dealer.

Вступ. За даними Державної служби статистики України [1] зниження обсягів будівництва у березні 2020 року склало $12,8 \%$.

Індекси бүдівельної продукції

( $\%$ до відповідного періоду попереднього року, наростаючим підсумком)

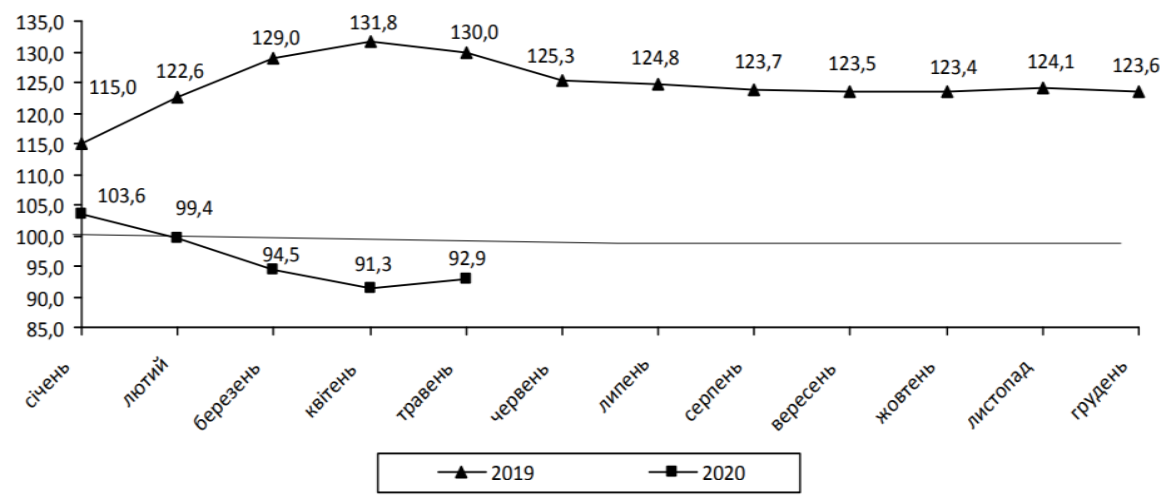

Рис. 1. Індекси будівельної продукції

«За січень - березень 2020 року підприємствами України виконано будівельних робіт на суму 26082,8 млн грн. Індекс будівельної продукції становить 94,5\% порівняно з відповідним періодом 2019 року. Нове будівництво склало 46,7\% від загального обсягу виробленої продукції, капітальний і поточний ремонти - 25,8\%, реконструкція та технічне переоснащення $-27,5 \%$ \% [2].

Постановка проблеми та задачі дослідження. Цьогорічний спад будівельної індустрії пов'язаний, звичайно, з пандемією COVID-19. Однак, навіть при певному спаді обсягів, об’єми робіт, які ведуться, є значними. 
Цілком закономірно, що дані роботи неможливо виконувати без вантажопідйомної техніки.

Будівельні машини, а особливо крани, працюють у складних умовах на різноманітних майданчиках, основах і об'єктах. Висока якість і точність виконання робіт поруч із надійністю, довговічністю і ремонтопридатністю техніки будуть вирішальними у виборі машини для виконання конкретної роботи. Тому надзвичайно важливими моментами $є$ можливість вчасно доставити кран, який повинен відповідати потребам замовника, вчасно проходити поточні і капітальні ремонти, технічні обслуговування, швидко забезпечити необхідними запасними частинами та матеріалами. Тому розвинена мережа сервісних підприємств в Україні може стати вагомим фактором при виборі як вантажопідйомної, так і іншої техніки.

Огляд пропозицій кранів у мережі [3] показав близько 5 тисяч пропозицій оренди та продажу кранів. Із даної вибірки можна зробити наступні висновки: при загальній кількості виробників 150 більше 10-20 пропозицій зустрічаємо від 33 виробників, а більше 50 - лише від 13 виробників будівельних кранів. Проаналізуємо пропозиції та сервіс від цих виробників на українському ринку вантажопідйомної техніки.

Офіційним дилером компанії Grove (США/Німеччина) в Україні виступає створена у 2003 p. Construction Machinery Ltd (CML). Вона має мережу сервісних центрів по всій Україні, а також мобільні сервісні бригади для оперативного реагування на звернення.

Основний виклад. «Компанія Grove була заснована в 1947 році і $\epsilon$ одним з лідерів у виробництві пересувних гідравлічних кранів. Виробничі потужності розташовані в Шейді Гров (Пенсільванія), Вільгельмсхафен (Німеччина) і Ніелла Танара (Італія). Компанія Grove належить до групи компаній Manitowoc Group, в яку також входить виробник баштових кранів Potaine, автокранів National Crane і гусеничних кранів 3 гратчастої стрілою Manitowoc» [4].

Компанія пропонує гідравлічні крани, які можна поділити на дві основні групи: вседорожні крани та крани для важкодоступної місцевості.

Вседорожні крани Grove маркуються як GMK, мають від 3 до 7 осей, вантажопідйомність від 50 до 450 т і висувну стрілу від 51 до 60 м. 


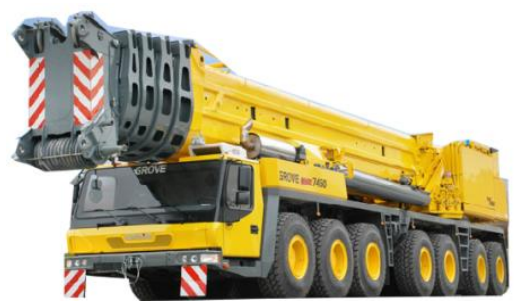

Рис. 2. Кран GMK 7450

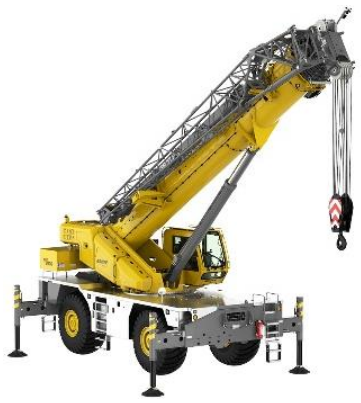

Рис. 3. Кран GRT 8120

Крани для важкодоступної місцевості Grove маркуються як RT чи GRT. Їх вантажопідйомність від 30 до 150 т і висувна стріла має довжину від 29 до 62,5 м.

У 2004 р. було створене ТзОВ «Юромаш» з іноземними інвестиціями. Воно $€$ ексклюзивним дилером в Україні компанії 3 виробництва будівельної техніки Hitachi Construction Machinery Co. Ltd., офіційним дилером в Україні компаній BELL, TEREX FINLAY та ін.

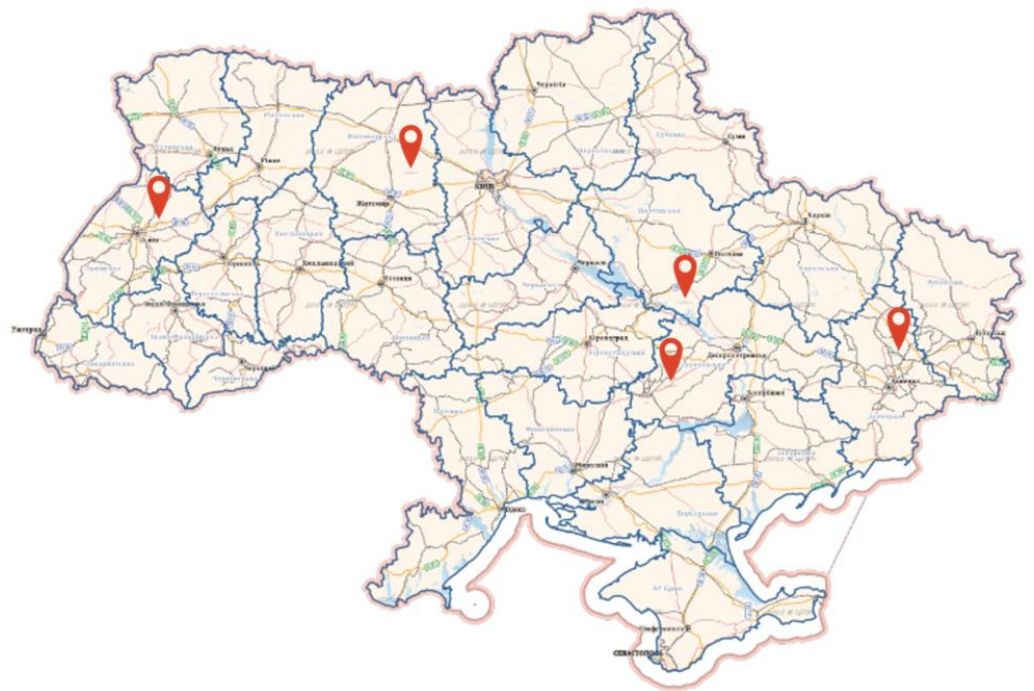

Рис. 4. Головний офіс і регіональні представництва «Юромаш»

Самохідні на гусеничному ходу крани Hitachi маркуються як SCX. Їх вантажопідйомність від 55 до 550 т і гратчаста стріла має довжину від 43,5 до 108,0 м. 


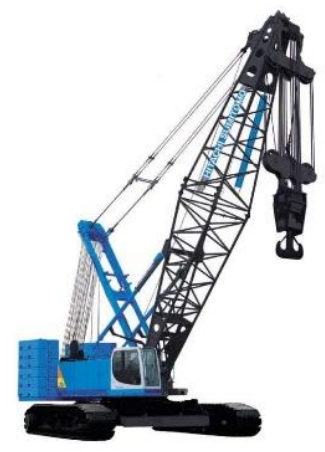

Рис. 5. Кран SCX2800A-2

У 2002 р. під назвою «Бобкет-Україна» була заснована компанія «Техноплаза Україна». На сьогодні вона $є$ офіційним дилером таких провідних виробників будівельної техніки як TEREX, KATO (Японія), TELTOMAT (Німеччина).

TEREX COMEDIL $є$ підрозділом корпорації TEREX (США). Вона випускає 47 моделей баштових кранів (для висотного будівництва, малоповерхового будівництва) і крани з підйомною стрілою.

Баштові крани Тerex виготовляються в наступних конструктивних варіантах: самомонтовані крани, крани без оголовка, крани із врівноваженою стрілою, а також крани з підйомною стрілою.

Крани без оголовка мають максимальну вантажопідйомність від 8 до 40 т та довжину стріли від 50 до 84 м.

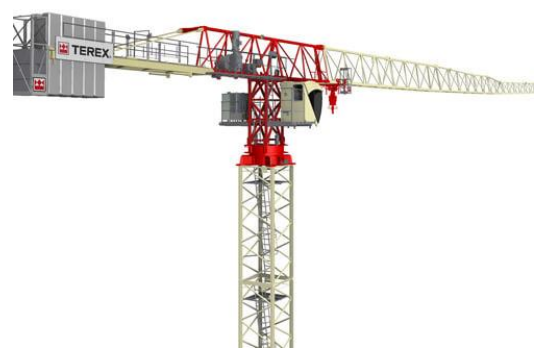

Рис. 6. Кран СТТ 162-8

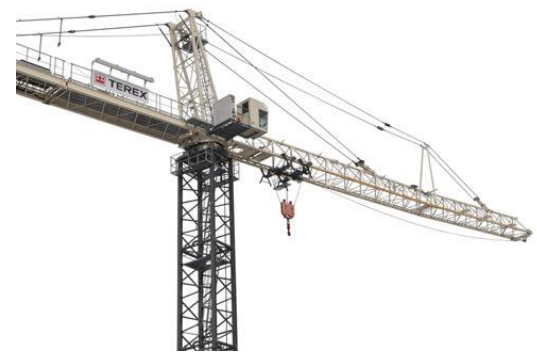

Рис. 7. Кран SK 415-20

Крани із врівноваженою стрілою мають максимальну вантажопідйомність від 20 до 32 т та довжину стріли 80 м. 
Баштові крани 3 підйомною стрілою серії Terex CTL мають максимальну вантажопідйомність від 10 до 66 т та довжину стріли від 50 до $75 \mathrm{м.}$

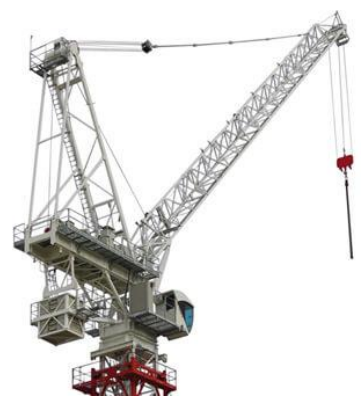

Рис. 8. Кран CTL 340-24

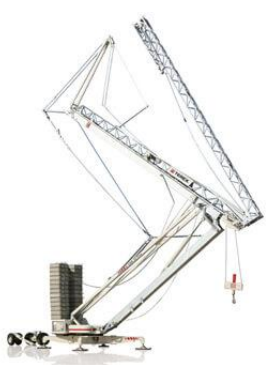

Рис. 9. Кран CBR 32 PLUS

Самомонтовані баштові крани Terex серії CBR мають максимальну вантажопідйомність від 1,6 до 4,4 т та довжину стріли від 21 до 40 м.

Всюдихідні стрілові крани Terex із телескопічною стрілою серій RT та TRT мають максимальну вантажопідйомність від 35 до 90 т та довжину стріли від 30 до 47 м.

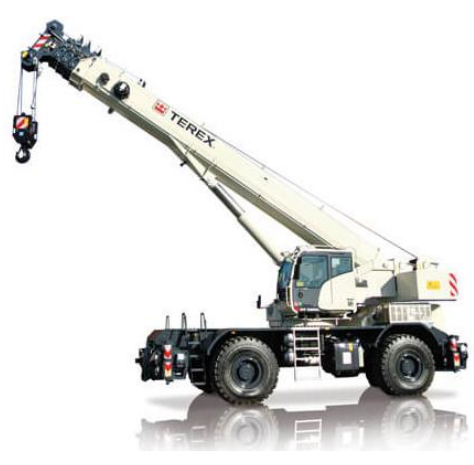

Рис. 10. Кран RT 1080L

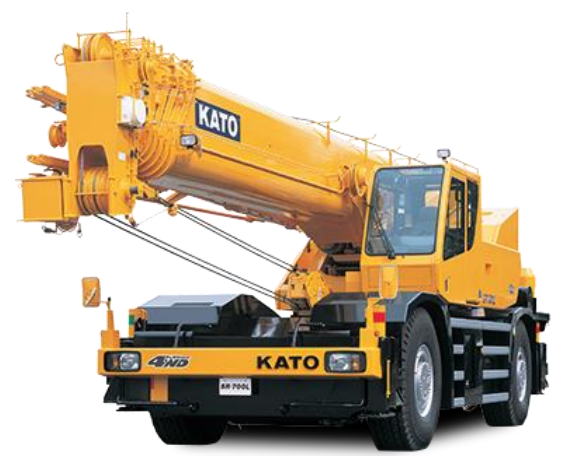

Рис. 11. Кран SR-700L

Крани для важкодоступної місцевості КАТО маркуються як SR. Їх вантажопідйомність від 30 до 70 т і висувна стріла має довжину від 9 до $44,5 \mathrm{~m}$.

Крани для міст КАТО маркуються як CR. Їх вантажопідйомність від 13 до 25 т і висувна стріла має довжину від 5,3 до 29 м. 


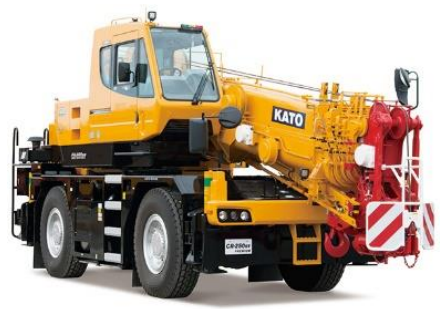

Рис. 12. Кран CR-250RV

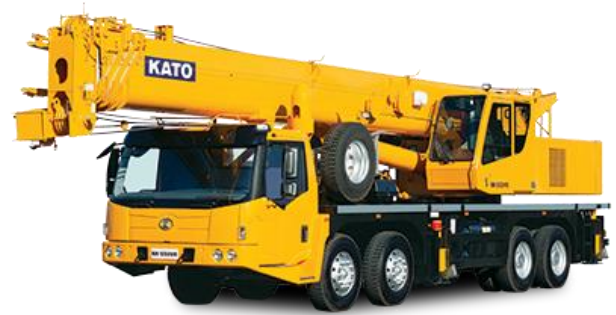

Рис. 13. Кран NK-550VR

Автокрани КАТО маркуються як NK. Їх вантажопідйомність від 30 до 60 т і висувна стріла має довжину від 10,6 до 43 м.

Гусеничні крани КАТО маркуються як ССН. Їх вантажопідйомність від 55 до 300 т і гратчаста стріла має довжину від 15 до 67 м.

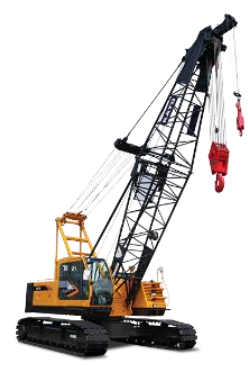

Рис. 14. Кран ССH550-3 II

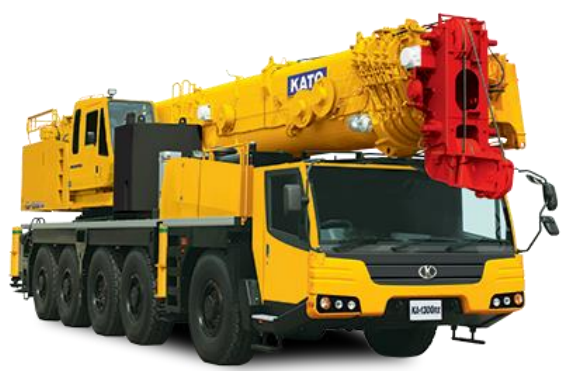

Рис. 15. Кран KA-1300RX

Універсальні крани КАТО маркуються як КА. Їх вантажопідйомність від 130 до 300 т і висувна стріла має довжину від 11,8 до 55 м.

Холдингова компанія Liebherr-International AG була заснована у 1949p. До неї входять 130 компаній, що випускають будівельну техніку, крани та самоскиди. Виробництво кранів становить третину доходів Liebherr. У світі компанія відома також як виробник холодильної техніки. 


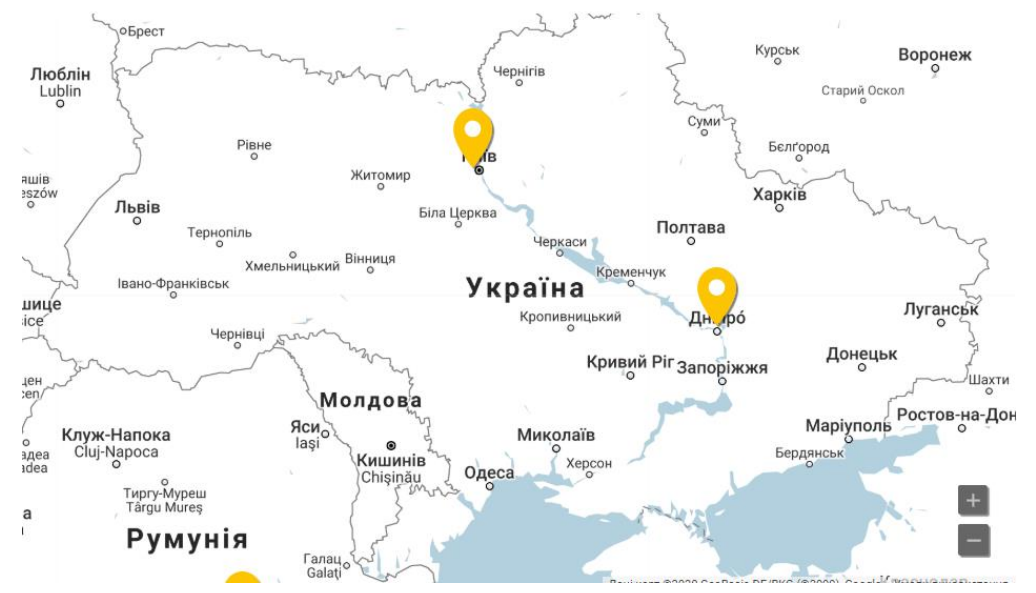

Рис. 16. Офіційні сервісні центри мобільних і гусеничних кранів Liebherr в Україні

Підприємство 3 іноземними інвестиціями у формі ТОВ «Німецьке індустріальне представництво» $є$ офіційним партнером Liebherr в Україні. Вони займаються продажем техніки, а також сервісом гусеничних кранів серії LR вантажопідйомністю до 300 т.

Ще одним офіційним партнером Liebherr в Україні $є$ ТОВ ТД АРМАДА ЛТД. Вони займаються продажем та сервісом баштових верхньоповоротних та швидкомонтованих кранів, гусеничних кранів серій LR вантажопідйомністю понад 300 т і LTR, всюдихідних короткобазових кранів LRT, автокранів LTF 3 телескопічною стрілою, компактних мобільних кранів LTC, кранів LG з гратчастою стрілою, мобільних кранів LTM та спеціальних кранів.

Зробимо невеликий огляд базових варіантів кранів Liebherr, які вирізняються багатою палітрою спеціалізованих машин.

\section{Швидкомонтовані крани}

Дана категорія кранів може успішно застосовуватись для будівництва індивідуальних та багатоквартирних будинків. При реалізації невеликих інфраструктурних проектів вони також знайдуть своє застосування. Тобто основна їх перевага - це швидке збирання та багатоваріантність застосування. 


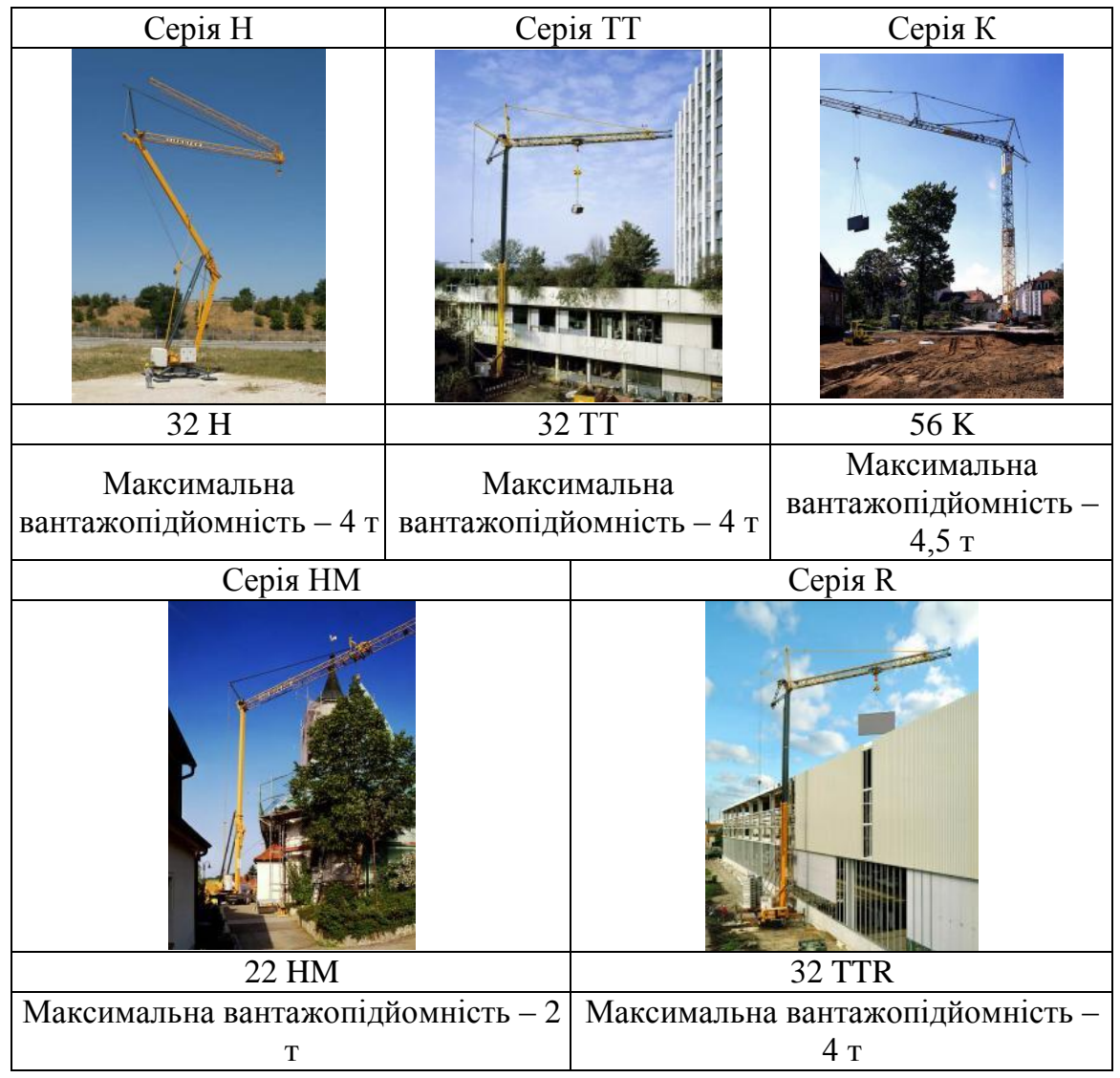

\section{Верхньоповоротні крани}

Завдяки модульній конструкції верхньоповоротні крани Liebherr чудово адаптуються до будь-яких індивідуальних потреб замовника.

Велика висота і швидкість підйому вантажу є суттєвою перевагою таких кранів. 


\begin{tabular}{|c|c|c|}
\hline Серія ЕС-В & Серія ЕС-H & Cepiя Heavy-Load HC \\
\hline & & \\
\hline Максимальна & Максимальна & Максимальна \\
вантажопідйомність - & вантажопідйомність - \\
$5 . .12$ т & $6 . .50 \mathrm{~T}$ & $\begin{array}{c}\text { вантажопідйомність } \\
-40 . . .100 \mathrm{~T}\end{array}$ \\
\hline
\end{tabular}

\begin{tabular}{|c|c|}
\hline Cерія Luffing HC-L & Серія Деррик DR \\
\hline & \\
\hline вантажопідйомність - & Максимальна вантажопідйомність - $10 \mathrm{~T}$ \\
\hline 12...54 т & 200 DR 5/10 Lіtronic \\
\hline
\end{tabular}

\section{Мобільні крани лінійки LTM}

Мобільні крани лінійки LTM мають шасі підвищеної прохідності. Вони можуть рухатись по дорогах загального користування і пересіченій місцевості. Відзначаються безпекою, економічністю i комфортом. Телескопічні стріли швидко і легко набирають робочу висоту.

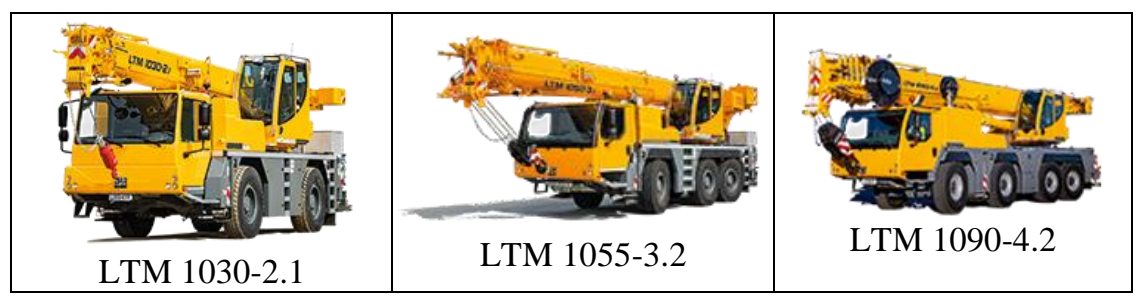




\begin{tabular}{|c|c|c|}
\hline 2-осний & 3-осний & 4-осний \\
\hline $\begin{array}{l}\text { Максимальна } \\
\text { вантажопідйомність - } \\
35 \ldots 40 \text { т } \\
\end{array}$ & $\begin{array}{l}\text { Максимальна } \\
\text { вантажопідйомність - } \\
50 \ldots 60 \text { т }\end{array}$ & $\begin{array}{l}\text { Максимальна } \\
\text { вантажопідйомність - } \\
70 \ldots 120 \text { т }\end{array}$ \\
\hline LTM 1110-5.1 & LTM 1300-6.2 & $\frac{1400-7.1}{\operatorname{LTM} 140}$ \\
\hline 5-осний & 6-осний & 7-осний \\
\hline $\begin{array}{l}\text { Максимальна } \\
\text { вантажопідйомність - } \\
95 \ldots .250 \text { т }\end{array}$ & $\begin{array}{l}\text { Максимальна } \\
\text { вантажопідйомність - } \\
300 \ldots 350 \text { т }\end{array}$ & $\begin{array}{l}\text { Максимальна } \\
\text { вантажопідйомність - } \\
400 \text { т }\end{array}$ \\
\hline & & $\begin{array}{l}\text { Типове позначення: } \\
\text { кран LTM 1230-5.1 } \\
1 \text { - лінійка продукції } \\
230 \text { - } \\
\text { вантажопідйомність, т } \\
5 \text { - кількість осей } \\
1 \text { - версія крана }\end{array}$ \\
\hline LTM 1650-8.1 & LTM 1750-9.1 & \\
\hline 8-осний & 9-осний & \\
\hline $\begin{array}{l}\text { Максимальна } \\
\text { вантажопідйомність - } \\
450 \ldots 700 \text { т }\end{array}$ & $\begin{array}{l}\text { Максимальна } \\
\text { вантажопідйомність - } \\
800 \ldots 1200 \text { т }\end{array}$ & \\
\hline
\end{tabular}

\section{Малогабаритні крани LTC}

Даний тип кранів з огляду на особливості конструкції підходить для підйомних робіт в умовах обмеженого простору (щільна міська забудова, промислові цехи). Варіативна концепція керування дозволяє швидко долати складні перешкоди, в т.ч. і під час руху.

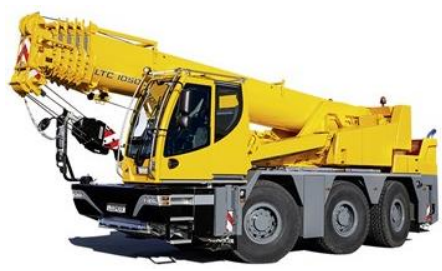

Рис. 17. Кран LTC 1050-3.1

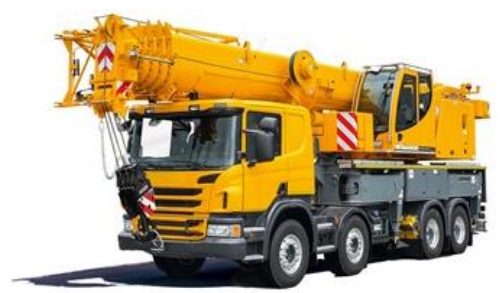

Рис. 18. Кран LTF 1060-4.1 


\section{Автомобільні телескопічні крани Liebherr LTF}

Вперше на шасі вантажного автомобіля телескопічний стріловий кран був змонтований у 1979 р. Ця група чудово зарекомендувала себе при необхідності короткочасних підйомів з постійними пересуваннями. Низькі експлуатаційні витрати за рахунок використання стандартних шасі вантажних автомобілів сприяють широкому використанню кранів.

\section{Всюдихідні крани LRT}

Всюдихідні крани мають високу надійність і потужність. Добре себе зарекомендували при роботі в умовах бездоріжжя.

Навіть у стандартній комплектації ці крани обладнані системою моніторингу аутригерів (виносних опор). Застосування виносних опор збільшує стійкість, а отже, і вантажопідйомність крана.

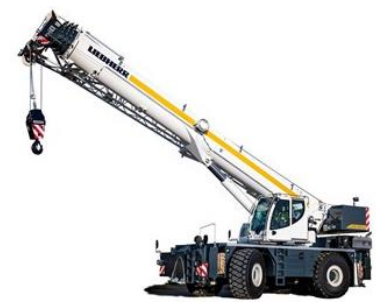

Рис. 19. Кран LRT 1100-2.1

\section{Мобільні крани Liebherr LG з гратчастої стрілою}

Висока мобільність разом із значною вантажопідйомністю дозволяє виконувати різноманітні складні задачі в різних дорожніх умовах без застосування сторонніх транспортних засобів.
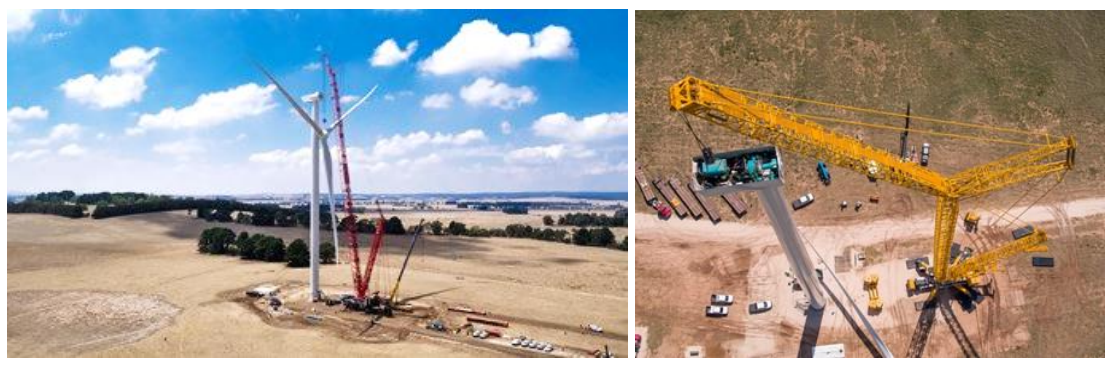

Рис. 20. Кран LG 1750 


\section{Гусеничні крани}

Гусеничні крани LR призначені для будівництва мостів, розширення портів, аеропортів, залізниць, спорудження підземних транспортних систем, зведення залізничних вокзалів. Гусеничні крани для висотного будівництва та інфраструктурних об'єктів мають вантажопідйомність від 110 до 3000 т.

LR $13000 €$ найпотужнішим у світі гусеничним краном традиційної конструкції. Основне застосування - будівництво електростанцій.

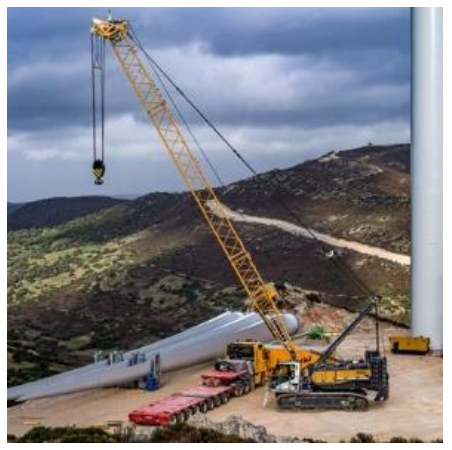

a)

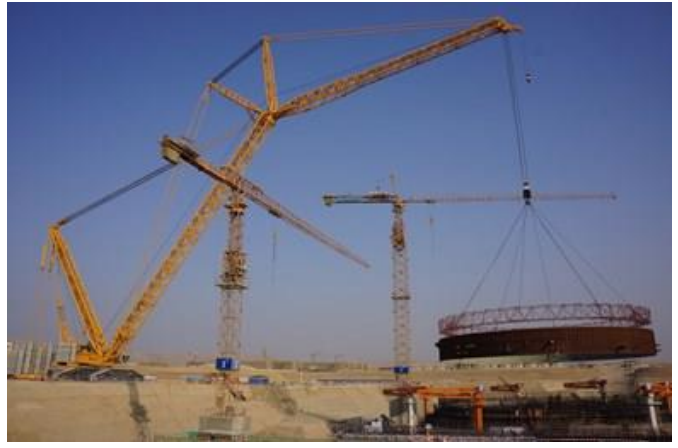

б)

Рис. 21. Гусеничні крани LR 1110 (а) та LR 13000 (б)

Гусеничні крани серії LTR поєднують в собі переваги всюдихідних і гусеничних. Їх можна використовувати на будь-якому майданчику. На відміну від колісних кранів, LTR може переміщатися з вантажем на гаку.

Крани мають дуже компактні розміри. На майданчику після транспортування низькорамним трейлером можуть збиратись методом самомонтажу. Шасі має змінну ширину колії, що забезпечується 3 допомогою гідравлічного приводу навіть у зібраному стані.

Вантажопідйомність кранів складає від 60 до 220 т. 


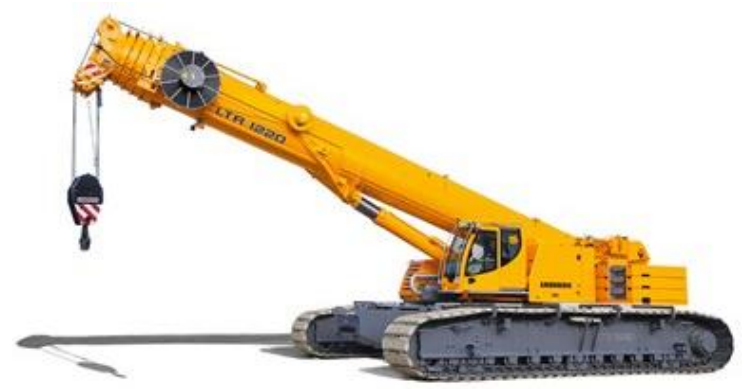

Рис. 22. Гусеничний кран LTR 1220

Обладнання фірми Liebherr реалізують також інші організації. Так, наприклад, компанія БУДТЕХНІКА КРАН БОР займається постачанням кранів, комплектуючих та електрообладнання до баштових кранів таких виробників як LIEBHERR, POTAIN, SAEZ та ін.

\section{Висновки}

1. Будівельний ринок потребує значної кількості підйомних машин різного призначення та характеристик.

2. В Україні $є$ ряд організацій зі значним досвідом $з$ продажу, ремонту та сервісного обслуговування кранів, які виступають у ролі офіційних дилерів та сертифікованих сервісних центрів.

3. На території України застосовується будівельна техніка усіх провідних світових виробників.

4. Пропозиція виробників кранового обладнання повністю перекриває потребу будівельного ринку у якісній підйомній техніці для виконання від найпростіших до найскладніших задач.

\section{References}

1. EXPRESS ISSUE. Production of construction products in January-May 2020. URL: http://www.ukrstat.gov.ua/express/expr2020/07/81.pdf (access date: 05.07.2020).

2. Passport of the construction industry, building materials industry as of 10.05.2020. URL: https://www.minregion.gov.ua/napryamki-diyalnosti/building/pricing/rozvitokbudivelnoyi-diyalnosti/pasport-budivelnoyi-galuzi-promyslovosti-budivelnyh-materialivstanom-na-10-05-2020/ (appeal date: 05.07.2020).

3. Cranes. URL: https://autoline.com.ua/-/krany--c119 (access date: 05.07.2020).

4. About Grove. URL: http://cml.ua/catalog/history/id/10?gclid=Cj0KCQjwl4v4BRDaARIsAFjATPkv7i8csmv FeOc22U4d7e3zKEWBgpI9Avh48GOZX0dpekLRydrCyWQaAj6MEALw_wcB (access date: 05.07.2020). 
5. Hitachi cranes. URL: https://www.hitachicm.eu/machinery/cranes/ (access date: 05.07.2020).

6. Tower cranes. URL: https://www.terex.com/cranes/ru/products/tower-cranes (access date: 05.07.2020).

7. Product Line Up. URL: http://www.katoworks.co.jp/eng/products/roughter/sr5001x.html (access date: 05.07.2020).

8. Tower Cranes and Mobile Construction Cranes. URL: https://www.liebherr.com/en/can/products/construction-machines/tower-cranes/towercranes.html (accessed 05.07.2020).

9. Mobile and crawler cranes. URL: https://www.liebherr.com/en/can/products/mobile-and-crawler-cranes/mobile-andcrawler-cranes.html (accessed: 05.07.2020).

\section{Список використаних джерел}

1. ЕКСПРЕС-ВИПУСК. Виробництво будівельної продукції у січні-травні 2020 року. URL: http://www.ukrstat.gov.ua/express/expr2020/07/81.pdf (дата звернення: 05.07.2020).

2. Паспорт будівельної галузі, промисловості будівельних матеріалів станом на 10.05.2020. URL: https://www.minregion.gov.ua/napryamkidiyalnosti/building/pricing/rozvitok-budivelnoyi-diyalnosti/pasport-budivelnoyi-galuzipromyslovosti-budivelnyh-materialiv-stanom-na-10-05-2020/ (дата звернення: 05.07.2020).

3. Краны. URL: https://autoline.com.ua/-/krany--c119 (дата звернення: 05.07.2020).

4. O Grove. URL:

http://cml.ua/catalog/history/id/10?gclid=Cj0KCQjwl4v4BRDaARIsAFjATPkv7i8csmv FeOc22U4d7e3zKEWBgpI9Avh48GOZX0dpekLRydrCyWQaAj6MEALw_wcB (дата звернення: 05.07.2020).

5. Hitachi cranes. URL: https://www.hitachicm.eu/machinery/cranes/ (дата звернення: 05.07.2020).

6. Башенные краны. URL: https://www.terex.com/cranes/ru/products/tower-cranes (дата звернення: 05.07.2020).

7. Product Line Up. URL: http://www.katoworks.co.jp/eng/products/roughter/sr500lx.html (дата звернення: 05.07.2020).

8. Tower Cranes and Mobile Construction Cranes. URL:

https://www.liebherr.com/en/can/products/construction-machines/tower-cranes/towercranes.html (дата звернення: 05.07.2020).

9. Mobile and crawler cranes. URL: https://www.liebherr.com/en/can/products/mobile-and-crawler-cranes/mobile-andcrawler-cranes.html (дата звернення: 05.07.2020). 